\title{
DEARTH, DIET, AND DISEASE IN IRELAND, 1850: A CASE STUDY OF NUTRITIONAL DEFICIENCY
}

by

\section{E. MARGARET CRAWFORD ${ }^{1}$}

DEATH and disease are no strangers to underdeveloped economies. At best, nutritional standards are poor: diets are inadequate in calories, protein, and vitamins. At worst, adverse weather conditions or pestilence or war can devastate the main food supply causing famine, disease, and death. These scourges are still familiar in Asia and Africa; in the western world such disasters have faded into the annals of time. Ireland experienced one of the last major famines to occur in Western Europe. Between 1845 and 1849, the potato crop failed three times, leaving about three million people destitute. In these years, both infectious diseases such as typhus, relapsing fever, and dysentery, and nutritional deficiency diseases were rife. Yet little has been written about the nutritional and medical aspects of Ireland's Great Famine. There is one very old study of scurvy in Ireland written at the time of the Great Famine, ${ }^{2}$ and a more recent general investigation of diseases prevalent during the Famine, ${ }^{3}$ but little else. This paper focuses attention on one particular nutritional deficiency disease xerophthalmia. Xerophthalmia is an eye disease caused by lack of vitamin A, and manifest by dryness and ulceration of the cornea.

In the first half of the nineteenth century, famines occurred in Ireland frequently. "In the three decades before the great famine one in every three years saw serious famine in some part of the country." Intense distress was suffered in 1817, 1822, $1831,1835-37,1839$, and 1842, culminating in the Great Famine. All these famines were caused by the failure of the potato crop, and in the case of the 1845-49 crisis a fungus disease, phytophthora infestans, more commonly referred to as potato blight, was the culprit. Since the potato was the main food, indeed often the only food, in the diet of the Irish labourers during the early decades of the nineteenth century, the effect of this pestilence was catastrophic for one-third of the population.

The course of the Great Famine has been well documented. The potato failure was only partial in $1845,{ }^{5}$ but the destruction of the crop was general and more widespread

\footnotetext{
' E. Margaret Crawford, BA, SRD, Department of Economic and Social History, Queen's University of Belfast, Belfast BT7 INN, Northern Ireland.

I wish to thank Dr L. A. Clarkson and Dr C. Ó. Gráda for helpful comments, and Mr S. S. Johnston, MB, DO, FRCS, who advised on the medical aspects of the documents.

$2 \mathrm{~J}$. O. Curran, 'Observations on scurvy as it has lately appeared throughout Ireland and in several parts of Great Britain', Dublin quart. J. med. Sci., 1847, 4: 83-134.

${ }^{3}$ W. P. McArthur, 'Medical history of the famine', in R. D. Edwards and T. D. Williams (editors). The Great Famine, Studies in Irish history 1845-52, Dublin, Brown \& Nolan, 1956, pp. 263-315. But see now Joel Mokyr, Why Ireland starved, London, Allen \& Unwin, 1983, which appeared while this paper was in the press.

‘ T. P. O’Neill, 'Poverty in Ireland 1815-45', Folklife, 1973, 11: 22.

s Cecil Woodham-Smith, The great hunger, London, Hamish Hamilton, 6th impression, 1980, p. 92.
} 


\section{E. Margaret Crawford}

in 1846 and 1848 . To a sizeable population used to a daily per capita consumption of potatoes of somewhere around ten to fourteen pounds for the adult male, the impact of the crop failure cannot be overstated. Distress and semi-starvation were usual experiences for a great number of the Irish population during two or three months each year, even in good seasons, ${ }^{6}$ but during the seasons of $1845,1846,1847,1848$, and part of 1849 , the scale of misery and starvation was unprecedented. How many died as a consequence of the Great Famine is not known precisely. Estimates vary from half a million by E. R. R. Green ${ }^{7}$ to around 800,000 by Cousens and O'Tuathaigh, ${ }^{8}$ while Cullen, McArthur and $\mathrm{O}^{\prime} \mathrm{Neill}^{9}$ believe the figure to be nearer the million mark. In more recent research Mokyr has convincingly argued for a figure in excess of one million. ${ }^{10}$

Why the Irish ltbouring classes experienced such an eresion of dietary variety down to one food, the potato, has been a point of debate among historians too. An older generation of writers viewed the labourers' monotonous menu as a manifestation of poverty. ${ }^{11}$ More recently, Professor Cullen has put forward a new proposition: he sees the commercialization of Irish agricultural products as the chief reason for reliance on the potato; ${ }^{12}$ it was bulky, difficult to transport and store and therefore less suitable for the market. ${ }^{13}$ It would be a mistake, however, to think that the Irish labouring classes were undernourished on this potato diet. On the contrary, the enormous quantities of potatoes consumed each day, accompanied with buttermilk or skimmed milk, provided the Irish labourer with not just a sufficiency of many nutrients, but a superabundance of some. The one chink in their nutritional armour was the fatsoluble vitamin A. Potatoes contain a negligible amount of vitamin A and although whole milk is a good source of beta-carotene, the pro-vitamin of vitamin A, skimmed milk and buttermilk contain only negligible amounts; and since both skimmed milk and buttermilk were often drunk instead of whole milk, for many the diet was virtually devoid of the vitamin.

A more detailed examination of the potato regime will highlight both its virtues and its defects. Although we know the pre-Famine Irish labourer ate large quantities of potatoes, the exact daily consumption is yet another disputed point. Connell estimated a figure of $10 \mathrm{lb}$. ;4 $^{14}$ Austin Bourke, in a very thorough study, calculated that for

\footnotetext{
- Between the end of the previous year's potato supply and start of the new season's crop a dietary hiatus occurred. Those labourers who could afford meal substituted it for potatoes, hence the phrase "the meal months". See J. Binns, The miseries and beauties of Ireland, London, Longman, Orme, Brown, 1837, vol.2, p.8.

'E. R. R. Green, 'Agriculture', in Edwards and Williams (editors), op. cit., note 3 above, p. 126.

'S. H. Cousens, 'Death rates in Ireland during the Great Famine', Population Studies, 1960, 14: 64; G. O'Tuathaigh, Ireland before the Famine 1798-1845, Dublin, Gill \& Macmillan, 1972, p. 204.

- McArthur, op. cit., note 3 above, p. 312; L. M. Cullen, Economic history of Ireland since 1660, Dublin, Batsford, 1972, p. 132; T. P. O'Neill, 'The organisation and administration of relief', in Edwards and Williams (editors), op. cit., note 3 above, p. 255.

10 J. M. Mokyr, 'The deadly fungus', Research in population economics, 1980, 2: 247.

"K. H. Connell, 'The potato in Ireland', Past and Present, 1962, 23: 60.

$12 \mathrm{~L}$. M. Cullen, The emergence of modern Ireland, 1600-1900, London, Batsford, 1981, p. 171; L. M. Cullen, 'Population growth and diet 1600-1850', in J. M. Goldstrom and L. A. Clarkson (editors), Irish population, economy, and society. Essays in honour of the late $\mathrm{K}$. H. Connell, Oxford, Clarendon Press, 1981, p. 105.

${ }^{13}$ Connell, op. cit., note 11 above, p. 59.

$14 \mathrm{~K}$. H. Connell, The population of Ireland 1750-1845, (reprint), Westport, Conn., Greenwood Press, 1975, p. 149.
} 
labourers living exclusively on the potato the basic daily portion was $12 \mathrm{lb}$., while for those living on a predominantly potato diet $8 \mathrm{lb}$. were eaten daily. ${ }^{15} \mathrm{~A}$ dietary survey carried out by the Poor Law Commissioners in 1839 among the labourers of counties Limerick, Tipperary, and Clare reveals an average daily consumption of almost $13 \mathrm{lb}$. $(12.8 \mathrm{lb}),.{ }^{16}$ while the Royal Commission of 1836 recorded in their Report $14 \mathrm{lb} .{ }^{17}$ The Poor Law Commissioners' dietary survey was sizeable, possibly representing about fourteen per cent of the labouring population. ${ }^{18}$ The information given in this dietary study provided the basis for a nutritional analysis shown in Table 1.

TABLE 1. NUTRITIONAL ANALYSIS OF THE AVERAGE DAILY DIET OF AN IRISH LABOURER, 1839

\begin{tabular}{|c|c|c|c|c|c|c|c|c|c|}
\hline \multirow{4}{*}{$\begin{array}{l}\text { Potatoes } \\
\text { Buttermilk }\end{array}$} & Quantity & Protein & Fat & Carbo- & Energy & Ca. & $\mathrm{Fe}$ & Vit A & Vit D \\
\hline & $\mathrm{g} / \mathrm{ml}$ & $\mathbf{g}$ & g & $\mathrm{g}$ & kcal & mg & $\mathrm{mg}$ & $\mu \mathrm{g} \mathrm{RE}^{* *}$ & $\mu \mathrm{g}$ \\
\hline & $5113^{*}$ & 71.6 & $\mathrm{Tr}$ & 1007.3 & 4090 & 220 & 24.5 & $\mathrm{Tr}$ & - \\
\hline & 1800 & 63.0 & 3.6 & 91.8 & 630 & 2178 & $\mathrm{Tr}$ & $\mathrm{Tr}$ & - \\
\hline & & 134.6 & 3.6 & 1099.1 & 4720 & 2398 & 24.5 & $\operatorname{Tr}$ & - \\
\hline
\end{tabular}

* This is an average figure taking account of seasonal eating patterns -2 meals when the days are short, 3 meals otherwise; and cooking losses.

** The recommended intake of vitamin A is $750 \mu \mathrm{g}$ Retinol Equivalents (Adults).

Figures for the nutritional analysis are from R. A. McCance and E. M. Widdowson, The composition of foods, London, Medical Research Council, 1960, and the fourth edition revised by A. A. Paul and A. T. Southgate; United States Department of Agriculture, Composition of foods, Agriculture Handbook, no. 8, Washington, 1950.

This exercise clearly demonstrates exceptionally high values of protein, carbohydrates, energy value (calories), and minerals, but also grossly deficient vitamin A and vitamin $\mathrm{D}$ levels. ${ }^{19}$ The diet was, however, partially redeemed at the season when whole milk was available. One pint of milk would have provided about $225 \mu \mathrm{g} \mathrm{RE}$ of vitamin $A$, still below the recommended intake, yet better than a diet devoid of the vitamin. When the potato crop was a success, the Irish labourer was on the whole well nourished; but when the potato harvest failed, this dependence on one crop which was so susceptible to the vagaries of weather and disease resulted in distress.

Desperation drove many into the much-hated workhouses during the crisis years of 1845-48. The Irish Poor Law system was still in its infancy at the outbreak of potato blight in 1845. Established in 1838, the first workhouses were opened in 1841 and the scheme was not completed until 1846 at the height of the catastrophe. The system in

${ }^{15} \mathrm{P}$. M. A. Bourke, 'The potato blight, weather, and the Irish Famine', unpublished PhD thesis, National University of Ireland, 1965, p. 95.

${ }_{16}$ Appendix to the sixth annual report of the poor law commissioners, Parliamentary Papers (hereinafter PP), 1840 (245) 17: 676.

17 Report of the poor inquiry commission, PP 1836 (42) 34: 692.

${ }_{18}$ The 1841 census of Ireland provides information of the quality of housing for each county, and the number of families living in each category of dwelling. Fourth-class housing was the poorest quality, consisting of a one-roomed cabin. Just over half a million labouring families lived in this type of housing, and it is from this group that the poor law inspector took his dietary survey. Fourteen per cent of those living in fourth-class housing resided in the counties of Tipperary, Limerick, and Clare.

19 Vitamin D may be acquired by man in two ways: through dietary sources and by synthesis through the action of ultra-violet light on the pro-vitamin 7-dehydrochclesterol which occurs naturally in the oily component of human skin. 


\section{E. Margaret Crawford}

Ireland was based initially on indoor relief only, that is, all those seeking relief had to submit to workhouse admission. Thus the workhouse by the very nature of its function became deeply involved in the famine crisis. As famine conditions intensified in 1846 and 1847 , the influx into the workhouses increased to a point of massive overcrowding. This overcrowding was most intense in the establishments in the south and west of the country, and ninety-three of the 130 workhouses housed more inmates than they were built to contain. ${ }^{20}$

The workhouse diet was modelled on that eaten by the poorest labourers in the country. Diet, just as every other aspect of workhouse administration, had to conform to the "less eligibility" principle, and the method chosen to achieve this premise was a reduction in the amount of food usually taken by the labourers. Three basic menus were planned by the Commission, from which each Board of Guardians had to select one. ${ }^{21}$ Not surprisingly, the main food was potatoes, 3 or $3 \frac{1}{2} \mathrm{lb}$. being the daily ration, depending on the menu selected: a mere collation for the labourer used to $10 \mathrm{lb}$. or 12 $\mathrm{lb}$. or more daily. Late in 1845 , the potato-based diet had to be abandoned when blight decimated the crop. In October 1845, a General Order was issued by the Poor Law Commissioners authorizing the Guardians to "depart from the established dietaries by substituting the use of oatmeal, rice, bread or other foods in lieu of potatoes".22

Indian meal became a very popular substitute for potatoes by the workhouse authorities. It was an imported grain, coming principally from America. ${ }^{23}$ Indian meal is a derivative of maize produced by grinding and milling the whole grain maize. When first imported into Ireland, the consignments were in the form of Indian corn. Indian corn is extremely hard, and in the Southern States of America, where it was a staple food, it was not ground but chopped in steel mills; such mills were not available in Ireland. Initially, therefore, the corn was very inadequately ground, and many people became ill after eating it; also the Irish were ignorant as to the correct method of cooking Indian meal. ${ }^{24}$ Furthermore, when first introduced, there was widespread abhorrence of the flavour of the food. As the grip of the famine tightened, however, Indian meal was refused less and less, and indeed it became quite popular. ${ }^{25}$

The attraction of Indian meal to the workhouse authorities was its cheapness compared with oatmeal, ${ }^{26}$ but it was no more acceptable within the workhouse than without when it was first placed on the menu. "Attempts to introduce it ... to replace potatoes caused riots; the inmates at Limerick refused to touch it." 27 Despite these teething problems, the workhouse management incorporated Indian meal into the diet

${ }^{20} \mathrm{O}$ 'Neill, op. cit., note 4 above, p. 245.

${ }^{21}$ Eighth annual report of the poor law commissioners, 1842: 24-27.

${ }^{22}$ Minute book of Antrim poor law union, PRO Northern Ireland BG1/1/1.

${ }^{23} 1846$ was not the first occasion Indian meal was imported into Ireland. Consignments arrived during the subsistence crises of 1800-1 and 1827. See CUST 15/103-105, PRO London; The diary of Humphrey O'Sullivan, edited by M. McGrath, London, Irish Texts Society, 1936, p. 51; E. Margaret Crawford, 'Indian meal and pellagra in nineteenth century Ireland', in Goldstrom and Clarkson (editors), op. cit., note 12 above, pp. 113-115.

${ }^{24} \mathrm{R}$. McHugh, 'The Famine in Irish oral tradition', in Edwards and Williams (editors), op. cit., note 3 above, p. 407.

${ }^{25}$ Woodham-Smith, op. cit., note 5 above, p. 74.

${ }^{26}$ The contract price of Indian meal to Clonmel Union in 1850 was $£ 77 \mathrm{~s}$. per ton; the oatmeal price was £9 13s. 4d. per ton. Minute book of Clonmel Union, BG67/4/11.

${ }^{27}$ Woodham-Smith, op. cit., note 5 above, p. 73. 
in several ways. Often it was made into stirabout; in some workhouses mixed with oatmeal, in others not, but in a number of establishments the only adjunct was a rationed quantity of milk, skimmed milk, or buttermilk. The quite enormous quantities of Indian meal served in certain Irish workhouses are noteworthy. In Castlebar and Tipperary workhouses the daily ration of Indian meal was $16 \mathrm{oz}$. (raw weight), and in Limerick workhouse $19 \mathrm{oz}$. was served each day. ${ }^{28}$

The quality of the workhouse diets sharply declined during the famine years. Many unions, especially those in the west and south-west where destitution was greatest, experienced financial difficulties at this time, so that food was often in short supply. In general, accounts were in a perilous state from 1846-49; and the diet deteriorated because Guardians' cheques were not honoured and frequently contractors refused to supply food. Evidence to this effect abounds in correspondence between the Boards of Guardians and Inspectors to the Poor Law Commissioners. ${ }^{29}$

Replacement of potatoes by farinaceous products also contributed to the deterioration in the nutritive quality of the workhouse diets. Although the nutritional standard of dietary regimes prior to the Famine exhibited several features indicative of an unbalanced diet, ${ }^{30}$ analysis also revealed some nutrients in abundance. ${ }^{31}$ For example, ascorbic acid (vitamin C) levels were exceptionally high in all the pre-Famine workhouse diets. The potato was solely responsible, for although it contains only a moderate amount of ascorbic acid the quantities consumed daily were sufficient to account for the high level. ${ }^{32}$ During the Famine, when the potato supply was cut off, evidence of a defect in the dietary alterations quickly appeared, not surprisingly, in the form of the nutritional deficiency disease, scurvy. Dr J. O. Curran, writing in the Dublin Quarterly Journal of Medical Science observed: "Scurvy, which formerly was the very rarest of diseases in Ireland has within the last two years been making its appearance in various towns and rural districts, and has latterly become exceedingly prevalent in all parts of the kingdom." ${ }^{33}$ Investigating the outbreak of scurvy in Dublin hospitals, Curran noticed that sixty per cent of the cases were in the North and South Union (workhouse) hospitals. Scurvy was easily diagnosed; it was familiar to the medical profession of the day: Lind's famous treatise on scurvy had been published in 1753. Other vitamin deficiency diseases had not yet been identified at the time of the Great Famine; nevertheless, as famine conditions intensified with each crop failure, multiple nutritional deficiencies were undoubtedly rife both outside and inside the workhouses.

Late in 1849, the Irish Poor Law Commissioners became greatly alarmed by an

${ }^{28}$ Returns from the county gaols and workhouses in Ireland of the daily diet allowed to an able-bodied man, PP 1847-8 (486) 53: 395, 396 and 399.

${ }^{29}$ Correspondence relating to the status of union workhouses in Ireland, PP 1847 (766) .4: 55, 74.

${ }^{30} \mathrm{~A}$ disproportionately high percentage of energy value (calories) was acquired from carbohydrates while too little was contributed by fats. Dietary levels of vitamin A and D were too low. See E. Margaret Crawford, 'Nutritional analysis of Irish workhouse diets', unpublished BA dissertation, Queen's University of Belfast, 1978, p. 85.

${ }^{31}$ Calcium, iron, and ascorbic acid (vitamin C) levels were very high, and the amount of protein and B complex vitamins were in adequate amounts. See ibid., p. 85.

${ }^{32}$ Ascorbic acid content was high even taking account of losses through storage, preparation, and cooking. Redcliffe N. Salaman, The history and social influence of the potato. Cambridge University Press, 1949, p. 304.

${ }^{33}$ Curran, op. cit., note 2 above, p. 84. 


\section{E. Margaret Crawford}

epidemic of what was described as ophthalmia prevailing in some workhouses. Ophthalmia was the description given to an infectious disease causing inflammation of the eyes, and dirty overcrowded conditions similar to those found in many Irish workhouses during the famine period were associated with the disease. So great was the concern of the authorities at the scale of the epidemic that the Poor Law Commissioners asked Arthur Jacob, Professor of Anatomy at the Royal College of Surgeons, and Sir William Wilde, a leading Dublin ophthalmic surgeon, to investigate the epidemic. ${ }^{34}$

Table 2 shows the dramatic increase in cases of so-called ophthalmia in the Irish workhouses between 1849 and 1852 .

$\begin{array}{lrrrr}\text { TABLE 2. THE NUMBER OF CASES OF OPHTHALMIA TREATED IN IRISH } & \text { WORKHOUSES } \\ & 1849 & 1850 & 1851 & 1852 \\ \text { Total number of cases in workhouse } & 13,812 & 27,200 & 45,947 & 31,876 \\ \text { Number of cases arising in workhouses } & 11,368 & 24,882 & 42,067 & 28,765 \\ \text { Number of cases admitted to workhouses with ophthalmia } & 532 & 758 & 963 & 1,360\end{array}$

(Source: Annual reports of the Poor Law Commissioners, 1850-53.)

Not only was there a rise in the incidence of the disease, but also there was a marked regional pattern. The unions which suffered most from ophthalmia were Clonmel, Cashel, Cork, Limerick, Kilrush, Kanturk, Kilmallock, Scariff, Millstreet, and Tipperary, ${ }^{35}$ all in districts where distress was most acute, though the epidemic was also prevalent farther north at Athlone, Ballinasloe, and at Galway in the west. ${ }^{36}$ In the Tipperary Union alone 2,068 cases of ophthalmia were recorded between 29 October 1849 and 12 August $1850 .{ }^{37}$

Professor Jacob was the first of the two physicians to investigate the epidemic. He was requested by the Poor Law Commissioners to visit the Athlone workhouse in December 1849 and examine the cases of ophthalmia there. In his report, the clinical evidence is rather superficial, more emphasis being given to prophylactic measures. Nevertheless, we do glean two important points. First, the disease was more prevalent among children than adults; second, he describes the children's diet, which consisted of only bread and milk. ${ }^{38}$ Sir William Wilde's report and letter to the Medical Attendants of the Tipperary Union following his visit there in August 1850 was more thorough and provides an excellent description of the eye diseases plaguing that institution. ${ }^{39}$ Wilde, too, noted that children were by far the more vunerable to attack, and those with obvious marks of starvation were also more susceptible. Dr Reardon, the Assistant Physician to the Tipperary Union, informed Wilde that "the class of patients attacked were debilitated, starved, female children, generally those recently admitted, worn out by previous want and privations of every kind - many having

\footnotetext{
${ }^{34}$ Fourth annual report of the commissioners for administering the laws for relief of the poor in Ireland, 1851: 130-151.

${ }^{35}$ Fifth annual report of the commissioners for administering the laws for relief of the poor in Ireland, 1852: 14 .

${ }^{36} \mathrm{~W}$. R. Wilde, Observations on the epidemic ophthalmia which had prevailed in the workhouses and schools of the Tipperary and Athlone union, Dublin, 1851, p. 27.

${ }^{37}$ Ibid., pp. 6-7; Fourth report, op. cit., note 34 above, p. 137.

33 Ibid., p. 133.

${ }^{39}$ Ibid., pp. 135-151.
} 
refused to come into the house [workhouse] in consequence of its crowded state, until they were exhausted to the last degree". ${ }^{40}$ The high incidence among children is an important diagnostic point in the disease, xerophthalmia, and it raises the possibility that some of those children were victims not of ophthalmia but of the nutritional deficiency disease, xerophthalmia.

Xerophthalmia is an eye disease caused by a lack of the fat-soluble vitamin A in the diet. Foods rich in this vitamin include fish liver oils, such as cod-liver oil, and red palm oil. Liver, butter, cream, cheese, whole milk, and egg yolk are good sources, but cereals, except maize, and potatoes do not contain the nutrient. ${ }^{41}$ Yellow maize contains the pro-vitamin cryptoxanthin, a form of vitamin A. ${ }^{42}$ Insufficiency or lack of vitamin A over a prolonged period leads to xerophthalmia, a damaging eye condition, which, if untreated, results in blindness. It is in overpopulated and poverty-stricken countries where dietary intake of vitamin $A$ is low that the associated deficiency is most prevalent. Ireland in the 1840 s certainly fitted these criteria. According to the 1841 census, the population had risen to almost 8.2 million, ${ }^{43}$ which was to prove to be its peak. As for poverty, it was the greatest social evil in pre-Famine Ireland. ${ }^{44} \mathrm{~A}$ measure of the magnitude of the problem is the succession of official inquiries on the subject during the opening decades of the nineteenth century. ${ }^{45}$ And furthermore, as Table 1 demonstrated, the daily diet of the peasantry at best was only marginally adequate in vitamin $\mathrm{A}$, and frequently lacking in the nutrient. In famine conditions such as those experienced during $1845-49$, the likelihood of finding this deficiency is strengthened. The number of families forced to exclude milk from their diet increased, for the solitary cow, common among the better-off labouring families, had to be sold to procure cash in order to buy some food during the early stages of the crisis. Later, Indian meal supplies arrived from America, but for many people even this food was unobtainable; either because they could not afford to purchase supplies despite the cheapness of the meal, or because they failed to qualify for outdoor relief, which was organized in 1847 by the Poor Law. ${ }^{46}$

We may now turn to the findings in Wilde's report and compare them with the incidence and clinical manifestations of xerophthalmia. The highest incidence of xerophthalmia is found among children. The reason for the vulnerability of this group may be lack of stores or small stores of vitamin A. Vitamin A is a storable vitamin, reserves being located in the liver. Adults usually have sufficient supplies to meet requirements for many months or even years. ${ }^{47}$ Children, on the other hand, have

${ }^{40}$ Ibid., p. 136.

${ }^{4}$ S. Davidson, R. Passmore, J. F. Block, and A. S. Truswell, Human nutrition and dietetics, 7th ed., Edinburgh, Churchill Livingstone, 1979, p. 120.

${ }^{42}$ P. Fisher and A. Bender, The value of food. Oxford University Press, 1979, p. 85.

${ }^{43}$ Census of Ireland, 1841, PP 1843 (504) XXIV.

44 O'Neill, op. cit., note 4 above, pp. 22-23; O'Tuathaigh, op. cit., note 8 above, p. 108.

45 Report from the committee respecting the poor in Ireland, 1804, reprinted in Report of the select committee on the state of the poor in Ireland, PP 1830, 7; Reports of the committee for inquiring into the condition of the poorer classes in Ireland, PP 1836, 30-34.

${ }^{46}$ Under the provisions of the Poor Law Amendment Act of 1847, outdoor relief was permitted initially to limited categories, though later this had to be relaxed. Relief was in the form of Indian meal rations.

${ }^{47}$ Davidson et al., op. cit., note 41 above, p. 119; H. A. P. C. Oomen, 'Xerophthalmia', in G. H. Beaton and J. M. Bengoa (editors), Nutrition in preventive medicine, WHO Monograph, Geneva, 1976, p. 94. 


\section{E. Margaret Crawiford}

smaller reserves which are quickly depleted, and, in addition, the greater demands of rapid growth in childhood places extra strain on their reserves, particularly when they are meagre. When Wilde visited the Tipperary Union, he found 340 cases of what was called ophthalmia in the workhouse hospital; 326 or almost ninety-six per cent of these were children; their ages ranging from four to fourteen years. Only fourteen patients were adults. ${ }^{48}$

How does the classical clinical picture of vitamin A deficiency fit the symptoms described by Wilde? The earliest symptoms of xerophthalmia are night-blindness, frequently followed by Bitot's spots ${ }^{49}$ and xerosis of conjunctiva. ${ }^{50}$ Wilde did not report any of these symptoms: they are rather subtle indicators which may have been overlooked or thought not worthy of note. It is at the more advanced stage of the disease that a very much stronger resemblance to some of Wilde's ocular descriptions is apparent. In xerophthalmia, irreversible damage to the eye occurs when ulceration has taken place, leading in advanced cases to complete perforation of the cornea with iris prolapse. Wilde observed among some of the Tipperary Union patients ulceration on the cornea of the eye: "several ... [ulcers] were nearly transparent, as if a piece had been clipped out of the cornea", ${ }^{31}$ and in other cases the corneal ulcers were totally transparent. Wilde continued by describing corneal changes in cases where the cornea had been ruptured, and a portion of the iris protruded, "producing either staphyloma or extensive leucoma with adhesion of [the] iris to the cornea". ${ }^{32}$ These clinical manifestations are very symptomatic of xerophthalmia.

Untreated xerophthalmia ultimately results in blindness, part or the whole of the cornea undergoing colliquative necrosis (softening) leading to deformation or destruction of the eyeball. This process is known as keratomalacia. Frequently, blindness occurs only in one eye. Here again, this pattern corresponds to that found by Wilde. Of the 340 cases he examined, sixteen had irrecoverably lost the sight in both eyes while thirty-two had lost vision in one eye, and a further thirty-three had one eye blemished so as to impair vision though not altogether to destroy sight. ${ }^{53}$ This trend is also reflected in the statistics on blindness for all the workhouses in Ireland in this period, as shown in Table 3.

TABLE 3. STATISTICS OF BLINDNESS IN IRISH WORKHOUSES 1849-51

One eye lost

Both eyes lost $1849 \quad 1850 \quad 1851$

$114 \quad 202 \quad 656$

(Source: Annual reports of the commissioners for administering the laws for relief of the $80 \quad 263$ 1851 and 1852.)

The most crucial test is dietary. We already know that the diet of the labourers outside the workhouse in the 1840s was deficient in vitamin A, and within the

\footnotetext{
48 Fourth annual report, op. cit., note 34 above, p. 137.

49 Bitot's spots are grey or whitish areas, cheese-like or foamy, occurring on either side of the cornea generally the lateral.

${ }^{\text {so }}$ Xerosis and Bitot's spots may also result from non-nutritional causes: See D. McLaren, Nutritional ophthalmology, London, Academic Press, 1980, p. 54-55.

${ }^{31}$ Fourth annual report, op. cit., note 34 above, p. 146.

32 Ibid., p. 145.

s3 Ibid., p. 140.
} 


\section{Dearth, diet, and disease in Ireland, 1850}

workhouse the nutritional standard of the diet was no better. Between 1848 and 1850 , the diet in the Tipperary workhouse was changed twice. On 29 December 1849, the new Master instructed the menu to be changed to the diet recommended by the Poor Law Commissioners the previous February. The dietary scale was divided into many classes according to age, sex, and state of health. As we are concerned primarily with children, we will consider the diet laid down for 5-9-year-olds. Table 4 illustrates the nutritional analysis of this diet.

TABLE 4. NUTRITIONAL ANALYSIS OF THE TIPPERARY WORKHOUSE DIET FOR CHILDREN AGED 5-9 YEARS $1849^{34}$

\begin{tabular}{|c|c|c|c|c|c|}
\hline Quantity & Protein & Fat & $\begin{array}{l}\text { Carbo- } \\
\text { hydrate }\end{array}$ & $\begin{array}{c}\text { Energy } \\
\text { Value }\end{array}$ & Vitamin A \\
\hline $\mathrm{g} / \mathrm{ml}$ & $\stackrel{g}{10}$ & $\begin{array}{l}g \\
47\end{array}$ & $\begin{array}{c}\mathrm{g} \\
88.4\end{array}$ & $\begin{array}{r}\text { kcal } \\
426\end{array}$ & $\mu \mathrm{g}^{*}$ \\
\hline 360 & 31.0 & 5.4 & 284.8 & 1246 & - \\
\hline 300 & 10.2 & 11.1 & 14.4 & 198 & 100 \\
\hline \multirow[t]{2}{*}{600} & 3.3 & 2.6 & 25.0 & 137 & - \\
\hline & 55.5 & 23.8 & 412.6 & 2007 & 131 \\
\hline
\end{tabular}

* $\mu \mathrm{g}$ Retinol Equivalents (RE)

** Bread calculated as 85 per cent extraction rate flour

*** The soup recipe was $8 \mathrm{oz}$. oatmeal to each gallon water seasoned with black pepper and salt, and thickened with turnips when convenient.

When one realizes that the present recommended intake of vitamin $A$ for children of that age ranges from 575 to $725 \mu \mathrm{gEE}$, the very poor content of this workhouse diet can be appreciated.

The best source of vitamin A in this menu was milk. But there was an option of replacing whole milk by buttermilk or skimmed milk, both of which have negligible amounts of beta-carotene. The temptation to make this substitution was great, as the price of buttermilk and skimmed milk was about half that of whole milk. Tipperary Union succumbed six months after the new diet was implemented. Up to the first week in June, milk was the only dairy beverage ordered. But on the first of June, new tenders for both milk and skimmed milk were recorded in the Minute Books: 5 pence per gallon for the former, and $2 \frac{1}{2}$ pence per gallon for the latter. ${ }^{35}$ The first estimate for milk and skimmed milk requirements following the new contracts demonstrates the cost consciousness of the union; 18,512 quarts of skimmed milk were requisitioned for the following week, but only 3,400 quarts of whole milk..$^{36}$ The Tipperary Union was in financial difficulties at this time. The audit revealed a debt amounting to $£ 11,800$, also considerable irregularities were discovered in the provisions ledgers. Yet the Tipperary Union was not the only one guilty of using the cheaper skimmed milk and buttermilk. Dr John Forbes visited numerous workhouses during his tour of Ireland in 1852, and he commented: "milk mentioned in the Irish dietaries is almost always buttermilk, sometimes it is ordinary skimmed milk, but I think, never (or very rarely)

\footnotetext{
${ }^{34}$ The diet is to be found in the rough minute book of the Tipperary Union, BG152/AA/1.

ss Minute book of the Tipperary Union, BG152/A/11.

56 Ibid.
} 


\section{E. Margaret Crawford}

fresh or new milk containing the cream". ${ }^{37}$ Not only was buttermilk and skimmed milk cheap, but also plentiful. As a by-product of butter production, large supplies of buttermilk were available, particularly in those regions where dairying was a major industry. Tipperary was just such a region. ${ }^{38}$

It is not altogether surprising, therefore, to find in the new dietary regime commenced in July 1850, the elimination of milk and in its place skimmed milk for all classes except the five-year-olds and under. As a consequence of this alteration, the nutritional status of the diet declined most significantly in vitamin A content, as shown in Table 5.

TABLE 5. NUTRITIONAL ANALYSIS OF THE TIPPERARY WORKHOUSE DIET FOR CHILDREN AGED 5-9 YEARS $1850^{59}$

\begin{tabular}{|c|c|c|c|c|c|c|}
\hline & Quantity & Protein & Fat & $\begin{array}{l}\text { Carbo- } \\
\text { hydrate }\end{array}$ & $\begin{array}{l}\text { Energy } \\
\text { Value }\end{array}$ & Vitamin A \\
\hline & $\mathrm{g} / \mathrm{ml}$ & g & $\mathrm{g}$ & $\mathrm{g}$ & kcal & $\mu g^{*}$ \\
\hline Indian meal & 120 & 11.0 & 4.7 & 88.4 & 426 & 31 \\
\hline Bread** & 300 & 25.8 & 4.5 & 237.3 & 1038 & - \\
\hline \multirow[t]{2}{*}{ Skimmed milk } & 1200 & 42.0 & 2.4 & 61.2 & 420 & $\mathrm{Tr}$ \\
\hline & & 78.8 & 11.6 & 386.9 & 1884 & 31 \\
\hline
\end{tabular}

${ }^{*} \mu \mathrm{g}$ Retinol Equivalents (R.E.)

** Bread calculated as 85 per cent extraction rate flour.

Further strong evidence we have for vitamin A deficiency disease being present among some of the patients suffering from eye disease in Tipperary Union comes from Wilde himself. Three times in his report he recommended the use of cod-liver oil for the treatment of certain patients. ${ }^{60} \mathrm{He}$ said: "Where the patient is much broken down in health, and that the disease is in a chronic stage, I beg to suggest the plentiful use of cod-liver oil, of which medicine a large supply should at once be procured, and a tablespoonful given to each child, two or three times a day. I saw I am sure fifty cases among those under your care which would be greatly benefited by the use of this remedy. It is most applicable to those cases in which there is much emaciation, paleness, a cold clammy skin, and large flabby granulations of the conjunctiva and sometimes transparent ulcers of the cornea." 61

That Wilde stumbled by chance on the effective treatment for xerophthalmia and keratomalacia with cod-liver oil is unquestionable. Keratomalacia was probably known to Wilde; the disease was described by physicians and ophthalmologists in the nineteenth century. ${ }^{62}$ However, the relationship between cod-liver oil, vitamin A, xerophthalmia, and keratomalacia could not have been known to Wilde; this conne-

37 J. Forbes, Memorandums of a tour in Ireland, London, Smith Elder, 1853, vol. 2, p. 232.

s8 Captain Hayes, a temporary poor law inspector for the union of Tipperary, in a letter to the Poor Law Commissioners commented on the extensive butter trade Tipperary had with England, PP 1847-8 (955) LVI, 612.

${ }^{99}$ Minute book of the Tipperary Union, BG152/A/11

${ }^{60}$ Fourth annual report, op. cit., note 34 above, pp. 145, 148, 150.

${ }^{61}$ Ibid., p. 145.

${ }^{62}$ McLaren, op. cit., note 50 above, pp. 50-51. 
xion was not discovered until later. Snell, in 1881, claimed therapeutic value in codliver oil for Bitot's spots; ${ }^{63}$ but it was not until 1913 that McCollum and Davis extracted the accessory food factor - fat-soluble A - (later to be called vitamin A) from cod-liver oil. ${ }^{4}$ Wilde may have been familiar with the work of George Budd, who in several articles ${ }^{65}$ described a number of vitamin deficiency diseases, one of which was undoubtedly what we now call xerophthalmia: he referred to it as dietary induced corneal ulceration in man. Yet Wilde's recommended treatment pre-dated the discovery of the precise nutritional links. He nevertheless prescribed the correct remedy for the cases in the Tipperary Union whose eye disease was xerophthalmia in its early stages.

Nineteenth-century Ireland was regarded by contemporaries as one of Europe's poorest and underdeveloped regions, but, unlike many present-day underdeveloped populations, the Irish were healthy and well nourished so long as their life-line, the potato, remained secure, but when the life-line failed the labouring classes were exposed to all the sufferings of dietary deficiency. Sir William Wilde provided us with an excellent study of one nutritional deficiency disease, xerophthalmia, evident in the wake of the Great Famine; a crisis which brought hunger and disease to a third of the Irish people.

${ }^{63} \mathrm{~S}$. Snell, 'On nyctalopia with peculiar appearances on the conjunctiva', Trans. Ophthal. Soc., U.K., 1881: 207-215.

${ }^{64} \mathrm{E}$. V. McCollum and M. Davis, 'The necessity of certain lipids in the diet during growth', J. Biol. Chem., 15: 167-175.

${ }^{65} \mathrm{G}$. Budd, 'Lectures on the disorders resulting from defective nutriment', Lond. med. Gaz. 1842: 743-749. 